\title{
Analisis Mutu Gula Merah Berbahan Dasar Tebu (Saccharum officinarum) Di Kabupaten Aceh Tengah
}

\author{
(Quality Analyzing of Brown Sugar made from Sugar Cane (Saccharum officinarum) \\ in Central Aceh District)
}

\author{
Mardan Syah Putra ${ }^{1}$, Eva Murlida ${ }^{1}, \operatorname{Irfan}^{1 *}$ \\ ${ }^{1}$ Program Studi Teknologi Hasil Pertanian, Fakultas Pertanian, Universitas Syiah Kuala
}

\begin{abstract}
Abstrak. Tanaman tebu menjadi komoditas perkebunan terbesar kedua yang terdapat di Kabupaten Aceh Tengah. Tanaman tebu diolah secara tradisional oleh masyarakat menjadi gula merah. Hal ini mengakibatkan beragamnya mutu yang dihasilkan. Penelitian ini bertujuan untuk mengkaji mutu dari gula merah tebu yang dihasilkan oleh industri gula merah tebu di Kabupaten Aceh Tengah. Hasil penelitian menunjukkan bahwa dalam hal kadar air, semua produk gula merah memenuhi Mutu SNI, dengan rincian sebanyak 33,3\% Mutu I dan 66,7\% Mutu II; dalam hal bahan tak larut air, sebanyak 33,3\% produk gula merah memenuhi Mutu II, sedangkan $66,7 \%$ lainnya belum memenuhi SNI; dalam hal kadar abu, sebanyak $25 \%$ produk gula merah memenuhi standar mutu SNI, sedangkan $75 \%$ lainnya belum memenuhi SNI; dalam hal glukosa, sebanyak 50\% produk gula merah memenuhi Mutu I, 16,6\% Mutu II, dan 33,3\% lainnya belum memenuhi SNI; dalam hal sukrosa, sebanyak 8,3\% produk gula merah memenuhi Mutu I dan 91,7\% lainnya belum memenuhi SNI; dan berdasarkan uji hedonik, sebanyak 58,3\% warna produk gula merah disukai panelis, $75 \%$ dalam hal aroma, 83,3\% dalam hal rasa, dan $58,7 \%$ dalam hal tekstur. Secara keseluruhan, 33,3\% produk gula merah tebu di Kabupaten Aceh Tengah telah memenuhi SNI, sedangkan 66,7\% lainnya belum memenuhi SNI.
\end{abstract}

Kata kunci: tebu, gula merah, standar mutu, Aceh Tengah.

\begin{abstract}
Sugar cane plantation is the second largest commodity in The Central Aceh District. The sugar cane plant is processed into brown sugar by local people in a traditional way that varies in qualities. This research was aimed to examine the quality of the brown sugar cane that is produced by the local industry in the Central Aceh District. The result of this reseach showed that in terms of water levels, all products of brown sugar meet the Indonesian National Standard (SNI) in which 33.3\% of the samples fulfilled the Quality I and the $66.7 \%$ met the Quality II. In terms of non-soluble materials, 33.3\% of the samples met the Quality II, whereas the other $66.7 \%$ did not meet SNI. In terms of ash content, $25 \%$ of the samples met the Quality I, whereas the other $75 \%$ did not met the SNI. In the terms of glucose content, 50\% of the samples met the Quality I, 16.6\% met the Quality II, and the other $33.3 \%$ did not met the SNI. In the terms of sucrose content, $8.3 \%$ of the sample met the Quality I and the other $91.7 \%$ did not met the SNI. Based on the hedonic test, panelists favored the color (58.3\%), aroma (75\%), flavor (83.3\%), and texture (58.7\%). Overall, 33.3\% sugar cane in Central Aceh District has met the SNI, whereas the other $66.7 \%$ has not met the SNI.
\end{abstract}

Key words: Sugar cane, brown sugar, quality standard, Central Aceh.

\section{PENDAHULUAN}

Tanaman tebu digolongkan ke dalam tanaman perdu dengan nama latin Saccharum officinarum. Tanaman tebu tumbuh di daerah tropika dan sub tropika sampai batas garis isoterm $20^{\circ} \mathrm{C}$ yaitu antara 190LU-350LS (Indrawanto dkk., 2010). Tanaman ini mengandung sekitar $20 \%$ air gula (nira) dari setiap batang yang diperas. Air perasan ini merupakan bahan baku dalam pembuatan gula merah dan gula pasir. Pertumbuhan tebu yang optimum dapat dicapai pada suhu antara $14^{\circ} \mathrm{C}-30^{\circ} \mathrm{C}$. Selain itu, tanaman tebu akan tumbuh lebih baik pada tanah dengan tekstur seperti lempung berliat, lempung berpasir, dan lempung berdebu (Setyamidjaja dan Husaini, 1992).

*Corresponding author: irfan.djailani@gmail.com

JIM Pertanian Unsyiah - THP, Vol. 2, No. 1, Februari 2017: 288-296 
Gula merah tebu dihasilkan dari proses pengentalan nira tebu dengan cara pemanasan. Pemanasan menjadi penting karena menentukan kualitas dari gula merah tebu. Pembuatan gula merah tebu secara tradisional memiliki kelemahan pada proses pemanasan, sehingga menghasilkan kualitas gula merah yang kurang baik. Penerapan teknologi sangat dibutuhkan dalam proses pemasakan nira tebu. Adanya perbaikan tahapan pengolahan, dapat meningkatkan kualitas gula merah tebu yang dihasilkan (Muhlisin dkk., 2015).

Mutu gula merah tebu sangat ditentukan oleh mutu dari bahan bakunya, seperti nira tebu. Selain itu, adanya bahan tambahan makanan yang digunakan serta proses pengolahan juga mempengaruhi mutu dari gula merah yang dihasilkan. Nira tebu dinyatakan telah rusak apabila komposisinya telah berubah menjadi asam dan berlendir. Kandungan sukrosa di dalam nira tebu mempengaruhi mutu gula merah. Terhidrolisisnya sukrosa di dalam nira tebu menjadi gula invert akan menyebabkan tidak dapat mengerasnya produk gula merah yang dihasilkan. Nira tebu yang mengandung gula invert yang tinggi juga akan menghasilkan gula merah yang berwarna gelap. Penambahan natrium metabisulfit menjadi alternatif agar gula merah dapat berwarna lebih terang (Lesthari, 2006).

\section{METODOLOGI PENELITIAN}

Tempat pengambilan sampel (sampling) untuk penelitian ini dilakukan pada 12 industri gula merah tebu di Kabupaten Aceh Tengah. Analisis mutu dari gula merah tebu dilakukan di Laboratorium Analisis Pangan Jurusan Teknologi Hasil Pertanian, Fakultas Pertanian, Universitas Syiah Kuala. Pengambilan sampel dilakukan pada bulan Februari (musim penghujan) sedangkan penelitian utama dilaksanakan pada bulan Maret-Juni 2016.

\section{MATERI DAN METODE}

\section{Bahan dan Alat}

Bahan utama yang digunakan pada penelitian ini adalah produk gula merah tebu yang diperoleh dari 12 industri gula merah tebu di Kabupaten Aceh Tengah. Bahan kimia yang digunakan dalam analisis antara lain: air suling, $\mathrm{Pb}$ Asetat, larutan $\left(\mathrm{NH}_{4}\right)_{2} \mathrm{HPO}_{4} 10 \%, \mathrm{HCl}$ $25 \%, \mathrm{NaOH} 30 \%$, Indikator fenolftalain, larutan luff, batu didih, es batu, KI $20 \%, \mathrm{H}_{2} \mathrm{SO}_{4}$ $25 \%, \mathrm{Na}_{2} \mathrm{~S}_{2} \mathrm{O}_{3} 0.1 \mathrm{~N}$ dan larutan kanji $0.5 \%$.

Peralatan yang digunakan pada penelitian ini antara lain cawan porselin, oven, desikator, timbangan analitik, kertas saring, tanur, labu ukur $250 \mathrm{ml}$, pipet tetes, labu ukur 100 $\mathrm{ml}$, termometer, penangas air, erlenmayer $500 \mathrm{ml}$, hot plate, stopwatch, kamera, lembar pengujian organoleptik, lembar wawancara daa wadah plastik.

\section{Penelitian Pendahuluan}

Populasi dalam penelitian ini adalah industri gula merah tebu di Kabupaten Aceh Tengah. Pemilihan lokasi sampel dilakukan secara acak dan didapatkan 12 industri gula merah yang dijadikan lokasi pengambilan sampel dalam penelitian.

\section{Penelitian Utama}

\section{Pengumpulan Data di Lapangan}

Menurut Sugiyono (2010), data yang didapatkan sebaiknya mampu menjelaskan alasan dari hasil penelitian yang ada. Pada penelitian ini, digunakan cara pengumpulan data dengan observasi, dokumentasi dan wawancara.

Analisis Mutu Gula Merah Berbahan Dasar Tebu (Saccharum officinarum) Di Kabupaten Aceh Tengah (Mardan 


\section{Analisis Sifat Kimia}

Gula merah tebu yang telah diperoleh selanjutnya dianalisis mutu kimianya, yang meliputi kadar air, bahan tak larut air, kadar abu, kadar sakarosa (sukrosa), kadar glukosa, dan uji organoleptik (warna, aroma, rasa dan tekstur) (AOAC, 1984).

\section{Rancangan Penelitian}

Penelitian ini menggunakan metode survey purposive random sampling, yaitu cara pengambilan sampel dengan memperhatikan pertimbangan yang dibuat oleh peneliti (Hadi, 2004).

\section{Analisis Data}

Analisis data dilakukan menggunakan program Microsoft Excel dalam bentuk histogram dengan tujuan mengevaluasi mutu dari gula merah tebu yang telah dianalisis.

\section{HASIL DAN PEMBAHASAN}

\section{Kadar Air}

Kadar air dinyatakan sebagai banyaknya air bebas yang terdapat di dalam suatu bahan pangan. Banyak atau sedikitnya jumlah air bebas di dalam bahan pangan umumnya berpengaruh terhadap mutu pangan. Persentase jumlah kadar air produk gula merah tebu pada 12 Industri Gula Merah Tebu di Kabupaten Aceh Tengah dapat dilihat pada Gambar 1.

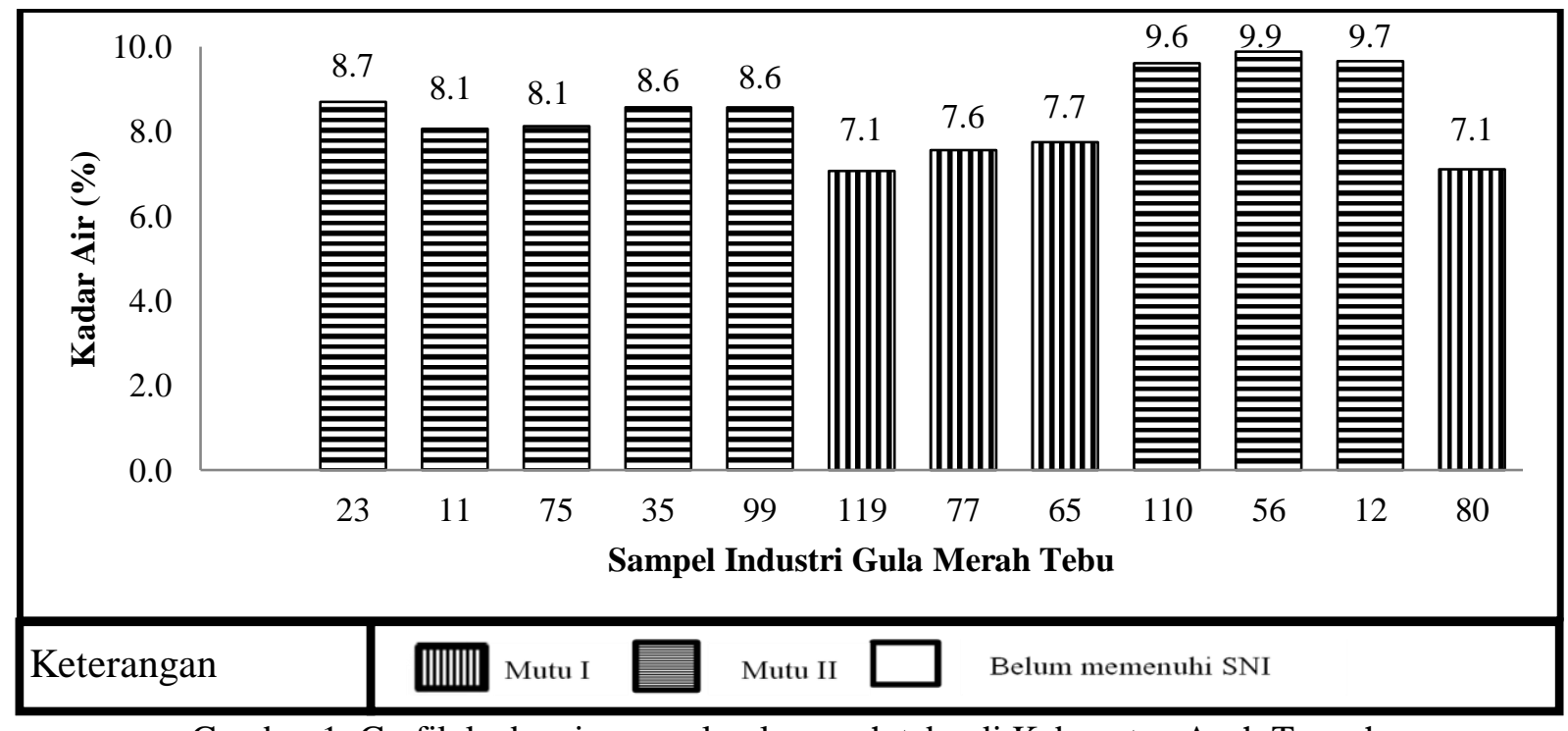

Gambar 1. Grafik kadar air sampel gula merah tebu di Kabupaten Aceh Tengah.

Dari Gambar 1, dapat dilihat bahwa terdapat 4 (empat) sampel gula merah tebu yang tergolong ke dalam Mutu I berdasarkan SNI (kadar air di bawah 8\%). Keempat sampel tersebut yaitu sampel 119 (kadar air 7.1\%), sampel 77 (7.6\%), sampel 65 (7.7\%) dan sampel $80(7.1 \%)$. Sedangkan untuk 8 (delapan) sampel lainnya tergolong ke dalam Mutu II berdasarkan SNI (kadar air diatas $8 \%$ ). Secara umum, kadar air gula merah tebu berkisar antara 7,1\%-9,9\% dengan rata-rata kadar air sebesar 8,3\%.

Analisis Mutu Gula Merah Berbahan Dasar Tebu (Saccharum officinarum) Di Kabupaten Aceh Tengah (Mardan 


\section{Bahan Tak Larut Air (Total Disoluble Solid)}

Menurut Susi (2013), bahan tak larut air merupakan kandungan padatan yang tidak dapat larut berupa kotoran yang terdapat di dalam gula. Grafik bahan tak larut air produk gula merah tebu di Kabupaten Aceh Tengah dapat dilihat pada Gambar 2.

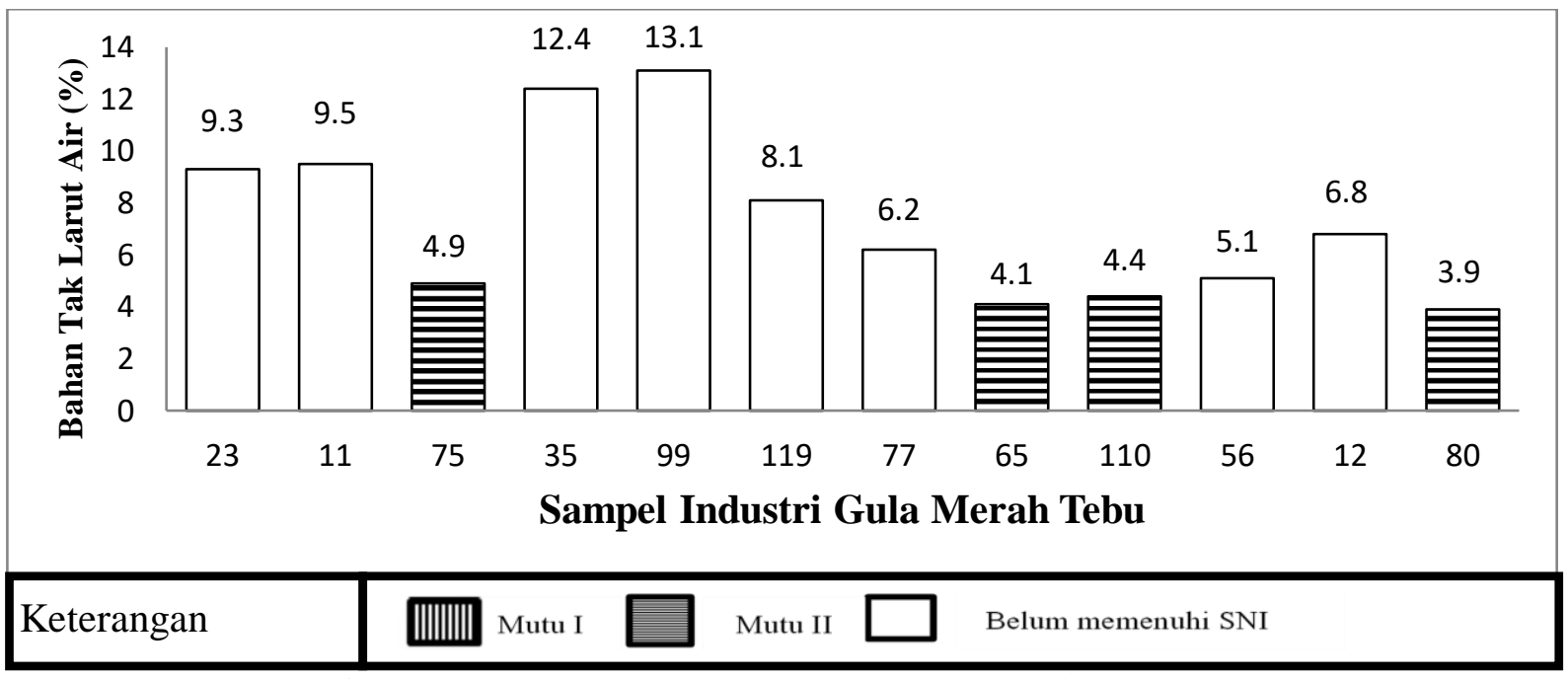

Gambar 2. Grafik bahan tak larut air sampel gula merah tebu di Kabupaten Aceh Tengah.

Berdasarkan Gambar 2, dapat dilihat terdapat keragaman mutu gula merah yang dihasilkan. Berdasarkan data hasil penelitian yang dilakukan, tidak terdapat industri gula merah tebu yang menghasilkan produk gula merah Mutu I (maksimal 1\%). Rata-rata sampel memiliki bahan tak larut air diatas 5\%, dengan kisaran 3,9\%-13,1\%. Hal ini menjelaskan bahwa produk gula merah tebu yang dihasilkan masih mengandung kotoran yang relatif tinggi.

\section{Kadar Abu}

Pengukuran kadar abu dilakukan dengan memasukkan sampel gula merah tebu ke dalam tanur dan dipanaskan pada suhu $550{ }^{\circ} \mathrm{C}$ hingga berat sampel konstan. Persentase jumlah kadar abu produk gula merah tebu pada 12 Industri Gula Merah Tebu di Kabupaten Aceh Tengah dapat dilihat pada Gambar 3.

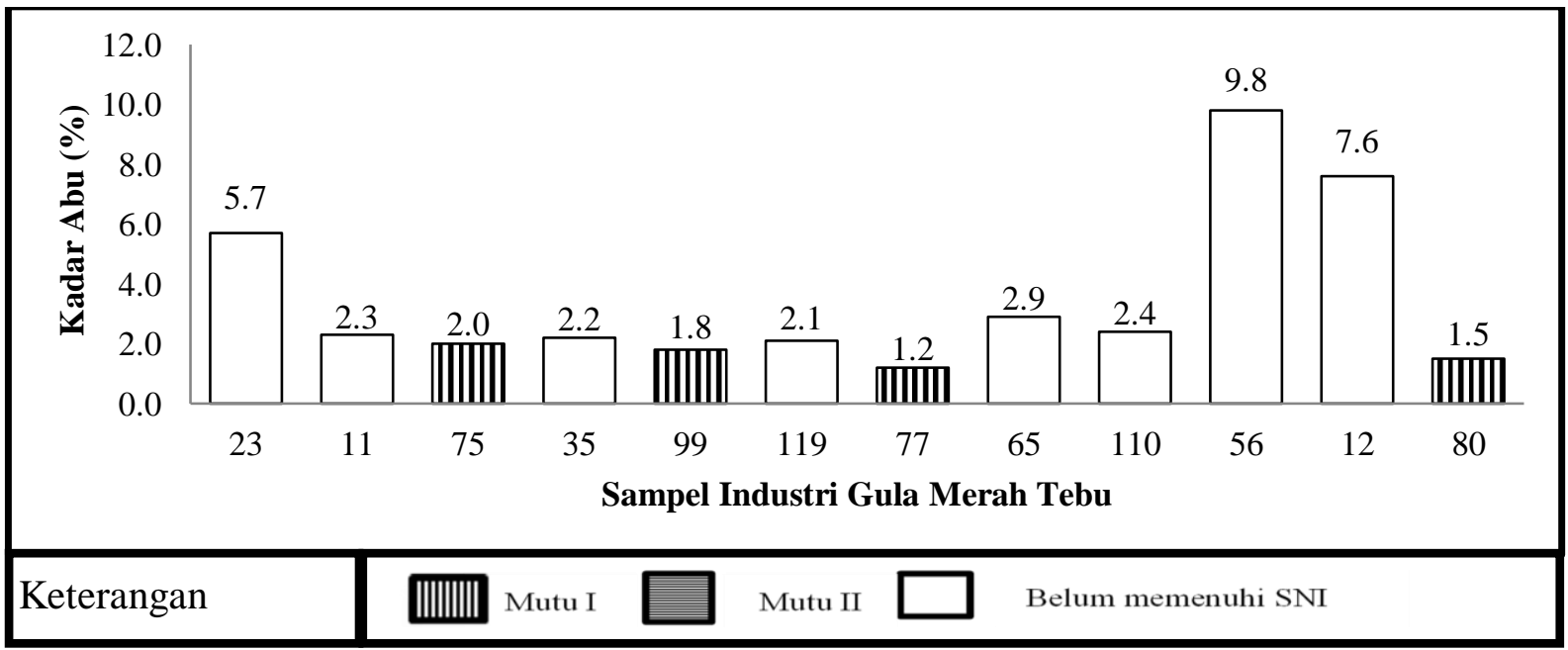

Gambar 3. Grafik kadar abu sampel gula merah tebu di Kabupaten Aceh Tengah.

Analisis Mutu Gula Merah Berbahan Dasar Tebu (Saccharum officinarum) Di Kabupaten Aceh Tengah (Mardan Syah Putra, Eva Murlida, Irfan)

JIM Pertanian Unsyiah - THP, Vol. 2, No 1, Februari 2017: 288-296 
Berdasarkan Gambar 3, terdapat variasi jumlah kadar abu yang didapatkan. Menurut SNI 01-3743-1995, kadar abu maksimal pada produk gula merah adalah sebesar $2 \%$. Berdasarkan data hasil pengamatan, sampel gula merah tebu mengandung kadar abu berkisar antara 1,2\%-9,8\%, dengan rata-rata 3,4\%. Tingginya kadar abu yang didapatkan pada sebagian sampel menunjukkan bahwa produk gula merah tebu yang dihasilkan tersebut masih memiliki mutu yang rendah. Terdapat 4 sampel gula merah yang memiliki kadar abu dibawah 2\% (memenuhi SNI), yaitu sampel 75 (2\%), 99 (1,8\%), 77 (1,2\%) dan $80(1,5 \%)$.

\section{Kadar Sakarosa (Sukrosa)}

Sukrosa pada gula merah tebu mempengaruhi sifat fisik dan organoleptik produk akhir. Kadar sukrosa produk gula merah tebu di Kabupaten Aceh Tengah dapat dilihat pada Gambar 4.

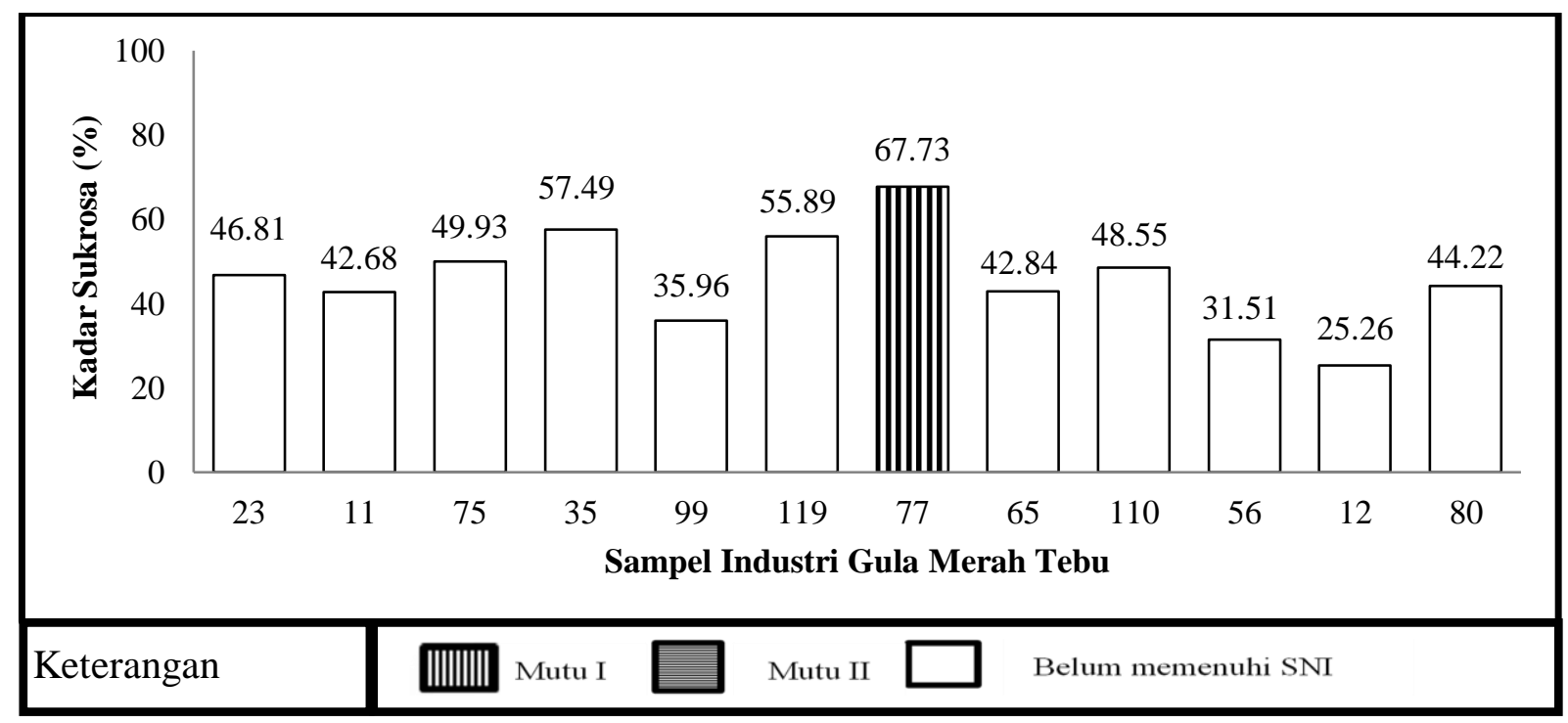

Gambar 4. Grafik kadar sukrosa sampel gula merah tebu di Kabupaten Aceh Tengah.

Berdasarkan Gambar 4, kadar sukrosa pada produk gula merah tebu yang dihasilkan oleh industri gula merah tebu masih sangat beragam, yaitu berkisar antara 25,26\%-67,73\%, dengan rata-rata 45,74\%. Kadar sukrosa tertinggi pada sampel $77(67,73 \%)$ dan tergolong ke dalam Mutu I, sedangkan sampel lainnya tidak termasuk ke dalam Mutu I dan II berdasarkan SNI. Menurut SNI I-6237-2000, kadar sukrosa gula merah tebu terbagi kepada dua golongan mutu, Mutu I dengan kadar sukrosa (minimal 65\%) dan Mutu II dengan kadar sukrosa (minimal 60\%).

Menurut Varina (1990), penundaan masa giling batang tebu dapat menurunkan kadar sukrosa yang dihasilkan. Hal ini dikarenakan terjadinya inversi sukrosa menjadi glukosa dan fruktosa oleh aktivitas mikroorganisme pada batang tebu dengan keadaan lingkungan penyimpanan yang asam.

\section{Kadar Glukosa}

Tinggi atau rendahnya kadar glukosa pada batang tebu sangat mempengaruhi produk akhir gula merah tebu yang dihasilkan. Semakin rendah kadar glukosa pada gula merah tebu maka akan semakin baik mutu gula merah tebu yang dihasilkan. Kadar glukosa produk gula merah tebu di Kabupaten Aceh Tengah dapat dilihat pada Gambar 5.

Analisis Mutu Gula Merah Berbahan Dasar Tebu (Saccharum officinarum) Di Kabupaten Aceh Tengah (Mardan 


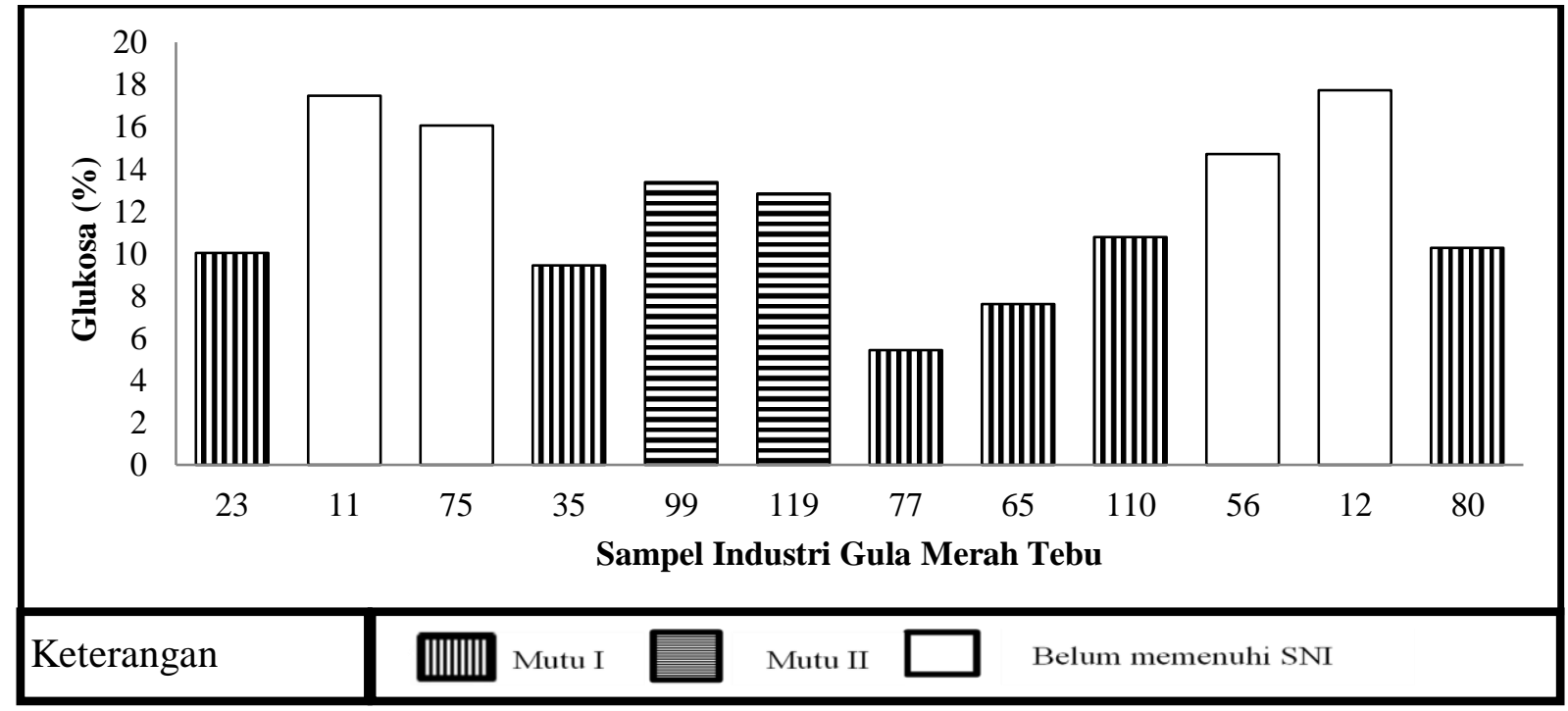

Gambar 5. Grafik kadar glukosa sampel gula merah tebu di Kabupaten Aceh Tengah.

Berdasarkan data pada Gambar 5, terdapat variasi kadar glukosa pada industri gula merah tebu di Aceh Tengah. Rata-rata kadar glukosa yang dihasilkan sebesar 12,15\% dengan kisaran kadar glukosa antara 5,43\%-17,73\%. Terdapat 6 sampel yang memiliki kadar glukosa dibawah 11\% (SNI Mutu I), yaitu sampel $77(5,43)$, sampel $65(7,61 \%)$, sampel $35(9,44 \%)$, sampel $23(10,03 \%)$, sampel $80(10,27 \%)$ dan sampel $110(10,78 \%)$.

\section{Organoleptik}

Warna

Tingkat kesukaan panelis terhadap warna produk gula merah tebu di Kabupaten Aceh Tengah dapat dilihat pada Gambar 6 .

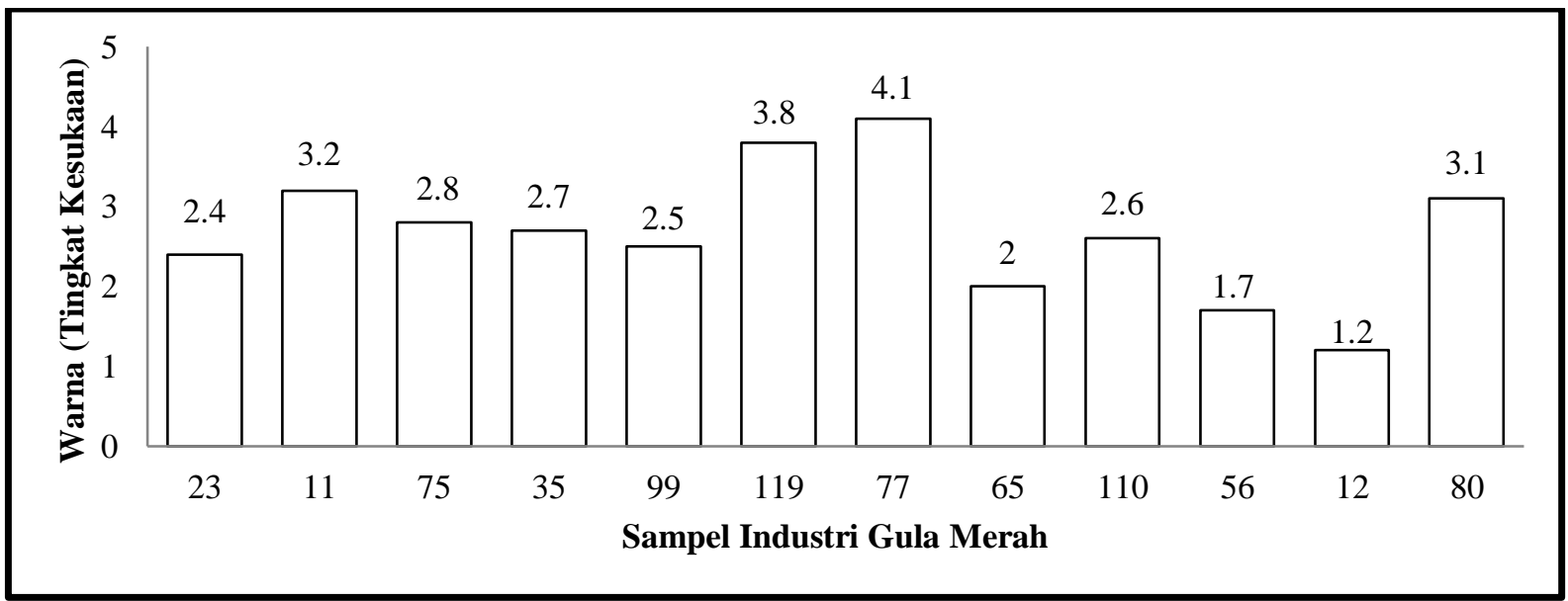

Gambar 6. Grafik uji hedonik warna sampel gula merah tebu di Kabupaten Aceh Tengah.

Berdasarkan Gambar 6, terdapat variasi tingkat kesukaan panelis terhadap warna sampel gula merah tebu. Produk gula merah tebu di Kabupaten Aceh Tengah memiliki warna yang bervariasi, mulai dari hitam, hitam kecoklatan, coklat, coklat kekuningan hingga kuning kecoklatan. Rata-rata panelis menyukai produk gula merah tebu yang memiliki warna coklat

Analisis Mutu Gula Merah Berbahan Dasar Tebu (Saccharum officinarum) Di Kabupaten Aceh Tengah (Mardan Syah Putra, Eva Murlida, Irfan)

JIM Pertanian Unsyiah - THP, Vol. 2, No 1, Februari 2017: 288-296 
kekuningan. Dari 12 sampel gula merah tebu yang disajikan, hanya terdapat 1 sampel yang disukai warnanya oleh para panelis, yaitu sampel 77 dengan nilai 4,1, satu lainnya yaitu sampel 119 mendekati suka dengan nilai 3,8. Sebanyak 9 sampel berada pada tingkatan netral hingga tidak suka, dan hanya 1 sampel yang berada pada tingkatan sangat tidak suka.

\section{Aroma}

Aroma menjadi salah satu atribut mutu yang harus diperhatikan pada setiap produk pangan. Menurut Nurlela (2002), gula merah tebu memiliki aroma khas asam dan sedikit karamel. Tingkat kesukaan panelis terhadap aroma produk gula merah tebu di Kabupaten Aceh Tengah dapat dilihat pada Gambar 7.

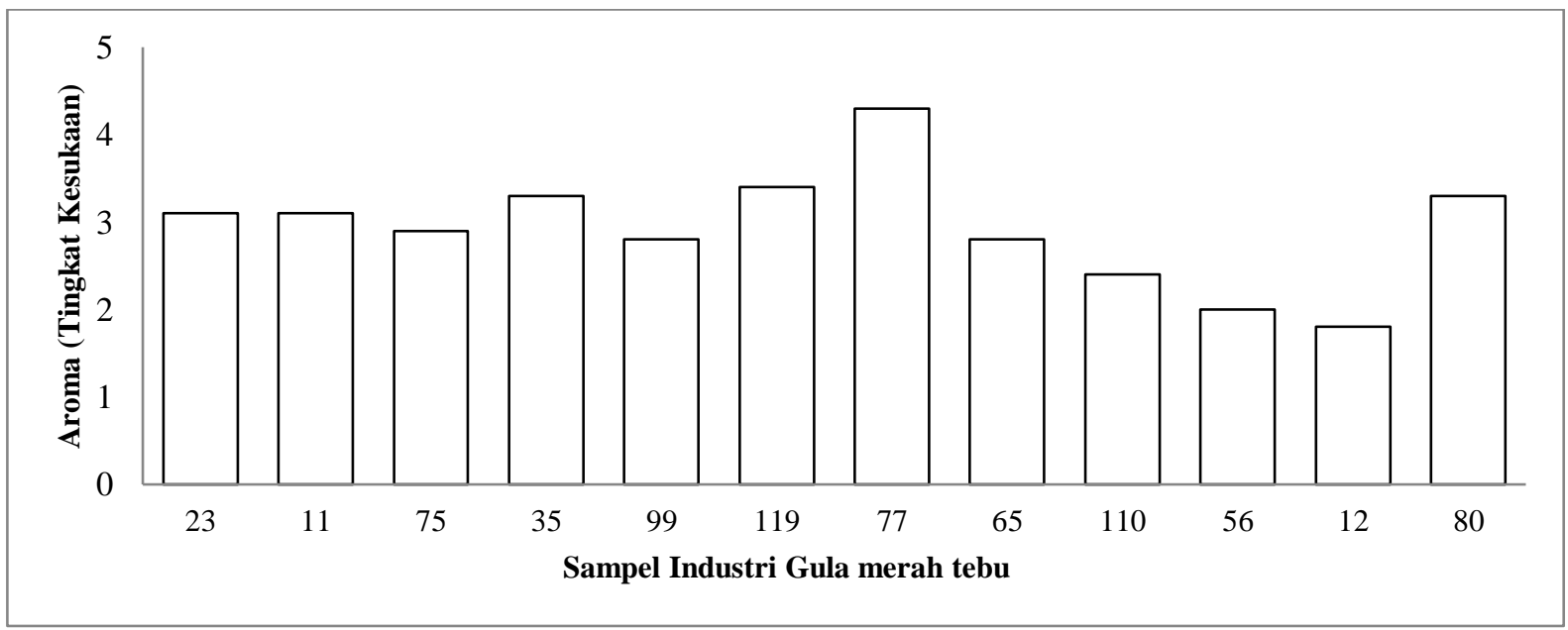

Gambar 7. Grafik uji hedonik aroma sampel gula merah tebu di Kabupaten Aceh Tengah.

Berdasarkan Gambar 7, terdapat variasi tingkat kesukaan panelis terhadap aroma gula merah tebu di Kabupaten Aceh Tengah. Dari 12 sampel yang dilakukan pengujian, hanya 1 (satu) sampel yang tingkat kesukaannya diatas 4 (suka), yaitu sampel 77 dengan nilai 4,3. Rata-rata sampel memiliki aroma produk gula merah tebu pada tingkatan netral.

Variasi aroma yang dihasilkan dipengaruhi oleh beberapa faktor. Secara umum, faktor bahan baku serta proses pengolahan sangat berperan pada pemunculan aroma produk gula merah tebu. Bahan baku yang segar akan menghasilkan aroma khas gula merah tebu, sedangkan bahan baku tebu yang sudah lama dilakukan penundaan giling akan menghasilkan aroma gula merah tebu yang gosong.

\section{Rasa}

Rasa menjadi salah satu atribut mutu yang sangat penting dalam penentuan mutu suatu produk bahan pangan. Gula merah tebu memiliki rasa yang khas, yaitu rasa manis dan sedikit asam. Rasa manis pada gula merah berasal dari kandungan gula berupa sukrosa, fruktosa, glukosa dan maltosa (Santoso dkk., 1993, di dalam Nurlela, 2002). Tingkat kesukaan panelis terhadap rasa produk gula merah tebu di Kabupaten Aceh Tengah dapat dilihat pada Gambar 8 . 


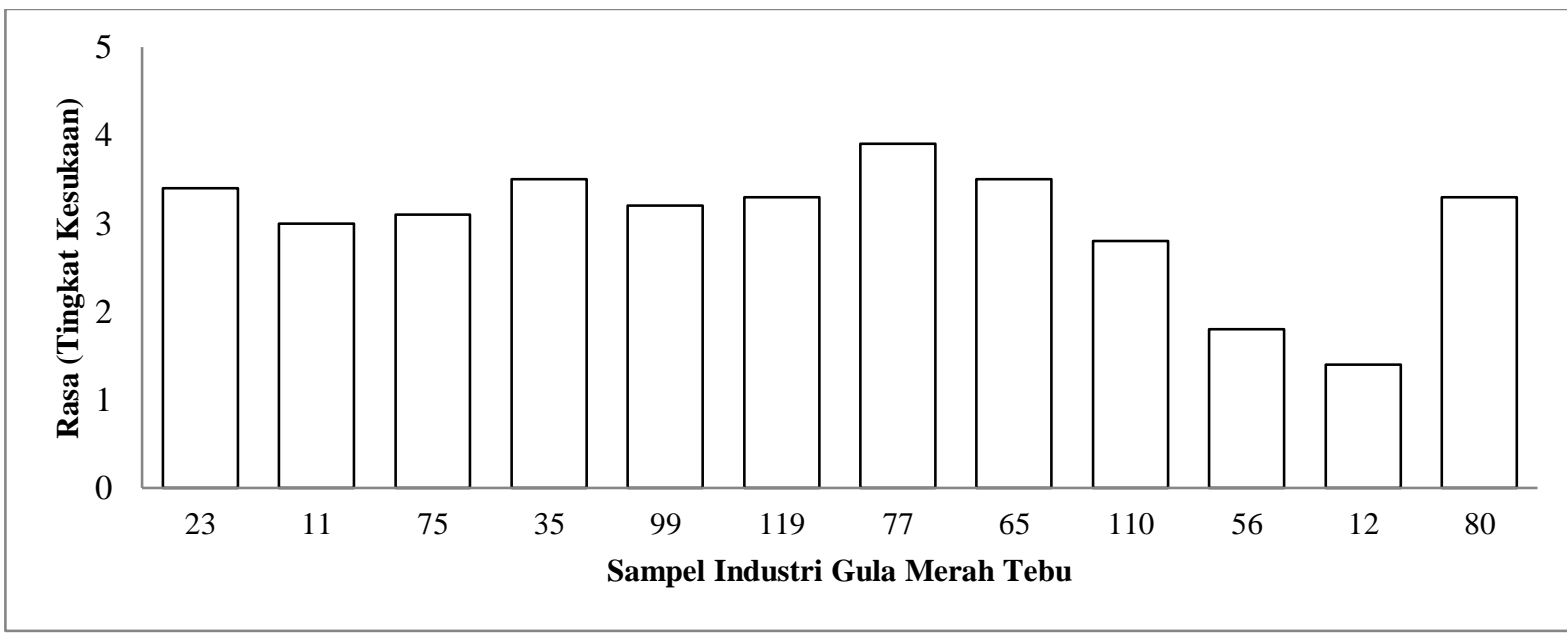

Gambar 8. Grafik uji hedonik rasa produk gula merah tebu di Kabupaten Aceh Tengah.

Berdasarkan Gambar 8, terdapat variasi tingkat kesukaan panelis terhadap sampel gula merah tebu di Kabupaten Aceh Tengah, terutama pada sampel 56 dan 12. Berdasarkan uji organoleptik rasa sampel gula merah tebu, rata-rata sampel gula merah memiliki nilai tingkat kesukaan pada tingkatan netral.

Berdasarkan SNI I-6237-2000, gula merah tebu memiliki rasa yang khas. Rata-rata sampel gula merah tebu yang diamati memiliki rasa yang manis dan sedikit asam. Rasa manis dan sedikit asam merupakan rasa khas yang disukai oleh para panelis.

\section{Tekstur}

Tekstur menjadi salah satu parameter mutu yang perlu diperhatikan pada bahan pangan. Tekstur berhubungan erat dengan jumlah kadar air dalam suatu bahan pangan. Tingkat kesukaan panelis terhadap tekstur gula merah tebu di Kabupaten Aceh Tengah dapat dilihat pada Gambar 9.

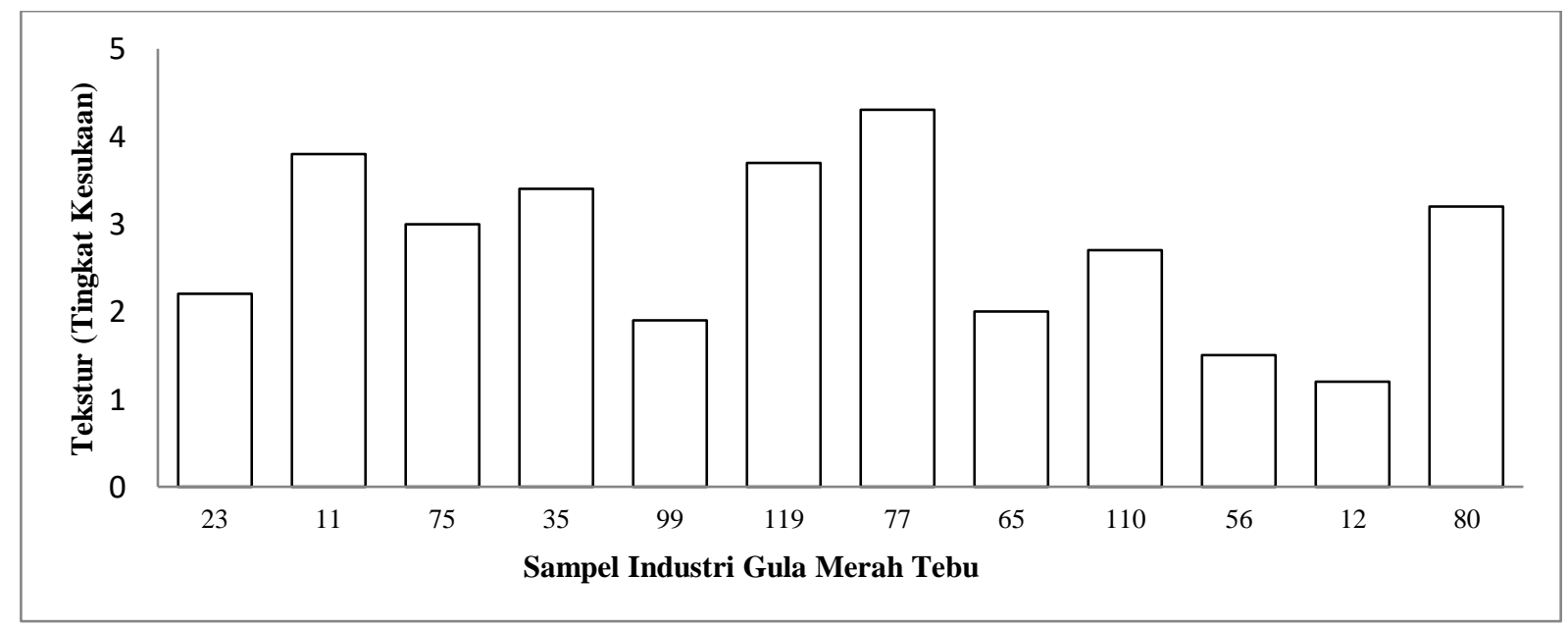

Gambar 9. Grafik uji hedonik tekstur sampel gula merah tebu di Kabupaten Aceh Tengah.

Berdasarkan Gambar 9, terdapat keberagaman tingkat kesukaan panelis terhadap tekstur gula merah tebu yang dihasilkan. Terdapat 5 sampel gula merah tebu, yaitu sampel 11, 75, 35, 119, 77 dan 80 dengan tingkat kesukaan netral sampai suka. Para panelis menyukai

Analisis Mutu Gula Merah Berbahan Dasar Tebu (Saccharum officinarum) Di Kabupaten Aceh Tengah (Mardan Syah Putra, Eva Murlida, Irfan)

JIM Pertanian Unsyiah - THP, Vol. 2, No 1, Februari 2017: 288-296 
tekstur gula merah yang tidak lengket. Tekstur gula merah yang rendah pada sebagian sampel diduga disebabkan oleh rendahnya mutu bahan dasar tanaman tebu dan proses pengolahan yang kurang baik.

\section{KESIMPULAN DAN SARAN}

Secara keseluruhan, 33,3\% produk Gula Merah Tebu di Kabupaten Aceh Tengah telah memenuhi standar mutu, sedangkan 66,7\% lainnya belum memenuhi SNI. Masih perlunya dilakukan perbaikan manajemen pengolahan industri gula merah tebu dari hulu hingga hilir di Kabupaten Aceh Tengah demi peningkatan mutu gula merah tebu yang dihasilkan serta perlunya penelitian lebih lanjut tentang kesesuaian penerapan teknologi pada proses pengolahan produk gula merah tebu di Kabupten Aceh Tengah.

\section{DAFTAR PUSTAKA}

AOAC. 1984. Official Methods of Analysis of The Association of Official Agricultural Chemist, Washington D. C.

Badan Standarisasi Nasional. 2000.SNI 01 - 6237 - 2000. Gula Merah Tebu. Badan Standarisasi Nasional, Jakarta.

Hadi, Sutrisno. 2004. Metodologi Research Jilid 3. Andi, Yogyakarta.

Indrawanto, C, Purwono, Siswanto, M. Syakir, \& W. Rumini. 2010. Budidaya dan Pasca Panen TEBU. Eska Media, Jakarta.

Lesthari, A. P. 2006. Pengaruh Waktu Tunda Giling Tebu dan Penambahan Natrium Metabisulfit terhadap Mutu Gula Merah Tebu. Fakultas Teknologi Pertanian Institut Pertanian Bogor, Bogor.

Muhlisin,A., Hendrawan,Y., \& Yulianingsih,R. 2015. Uji Performansi dan Keseimbangan Massa Evaporator Vakum Double Jacket Tipe Water Jet dalam Proses Pengolahan Gula Merah Tebu (Saccharum officinarum L.). Jurnal KETEKNIKAN PERTANIAN TROPIS DAN BIOSISTEM, Volume 3, Nomor 1, Hal. 24 - 36.

Setyamidjaja \& Husaini. 1992. Tebu : Bercocok Tanam dan Pascapanen. Yasaguna, Jakarta.

Sugiyono. 2010. Metode Penelitian Kuantitatif Kualitatif dan RND. Alfabeta, Bandung.

Varina, F. 1990. Pembuatan gula semut dari batang tebu (Saccharum officinarum L.) yang ditunda ekstraksi niranya. Fakultas Teknologi Pertanian IPB, Bogor.

Analisis Mutu Gula Merah Berbahan Dasar Tebu (Saccharum officinarum) Di Kabupaten Aceh Tengah (Mardan 